\title{
Efficacy of azithromycin in the treatment of cutaneous leishmaniasis
}

\author{
Eficácia da azitromicina no tratamento da leishmaniose cutânea
}

\author{
Aluízio Prata ${ }^{1}$, Mario Léon Silva-Vergara ${ }^{1}$, Laércio Costa ${ }^{2}$, Ademir Rocha $^{3}$, Alejandro Krolewiecki ${ }^{4}$, \\ Jaime Costa Silva ${ }^{5}$, Edvá Vieira de Paula ${ }^{5}$, Fabiano Geraldo Pimenta Junior ${ }^{5}$ and \\ Luiz Eduardo Ramirez Giraldo'
}

\begin{abstract}
The present open pilot study was conducted to assess the efficacy of azithromycin for the treatment of patients with cutaneous leishmaniasis in Araçuaí and Varzelândia, MG. Twenty-four patients with less of six months of disease evolution were treated after clinical examination, Montenegro test and a biopsy. The treatment schemes consisted of oral doses of $500 \mathrm{mg}$ per day for 3,5 and 10 days and of $1000 \mathrm{mg}$ for two days. A clinical control was performed monthly and treatment cycles were repeated when necessary until full reepithelialization of the lesions. On the occasion of the final evaluation, 20 patients had completed the study and 17 of them $(85 \%)$ were cured. The time to obtain a cure was 60 days ifor $6(30 \%)$ patients, 90 days for $7(35 \%)$, and 120 for 4 (20\%). The three patients with treatment failure received a pentavalent antimonial for 20 days. No adverse reactions to the medication were observed and a 14 month follow-up did not show recurrence in any patient.

These results suggest that azithromycin can be a good therapeutic option for the treatment of cutaneous leishmaniasis caused by Leishmania Viannia brasiliensis.
\end{abstract}

Key words: Cutaneous leishmaniasis. Azithromycin. Leishmania Viannia brasiliensis.

Resumo O presente estudo piloto aberto avaliou a eficácia da Azitromicina em pacientes com leishmaniose cutânea, em Araçuaí e Varzelândia, MG. Foram tratados 24 pacientes após exame clínico, teste de Montenegro, e biópsia, e que tivessem menos de seis meses de evolução da doença. Os esquemas de tratamento empregaram doses, pela via oral, de $500 \mathrm{mg}$ por dia durante 3,5 e 10 dias e de $1000 \mathrm{mg}$ durante dois dias. Mensalmente foi realizado controle clínico e quando necessário, repetidos ciclos do medicamento, até reepitelização completa das lesões. Na avaliação final 20 pacientes terminaram o estudo, dos quais 17 (85\%) foram curados. O tempo de cura foi de 60 dias em 6 (30\%) pacientes, de 90 dias em 7 (35\%) e de 120 dias em $4(20 \%)$. Os três pacientes que tiveram falha terapêutica receberam antimonial pentavalente durante 20 dias. Não foram observadas reações adversas ao medicamento e o seguimento até 14 meses pós-tratamento não mostrou recidiva em nenhum dos pacientes. Estes resultados sugerem que a Azitromicina pode ser uma boa opção terapêutica para o tratamento de leishmaniose cutânea causada por Leishmania Viannia brasiliensis.

Palavras chaves: Leishmaniose cutânea. Azitromicina. Leishmania Viannia brasiliensis.

The treatment of leishmaniasis has been classically based on meglumine antimoniate (Glucantime) ${ }^{\circledR}$ and on sodium stibogluconate $\left(\right.$ Pentostam) ${ }^{\circledR}$. Other therapeutic options of proven efficacy are amphotericin B, pentamidine and aminosidine ${ }^{12,13,17}$. All of these drugs are administered by the parenteral route, present several side and toxic effects and must be used for several weeks ${ }^{5,18}$. Oral medications such as imidazole and triazole derivatives and allopurinol, among others, have been used, with variable responses ${ }^{1,3}$.
The availability of an effective medication administered by the oral route and effective against leishmaniasis would be highly relevant. Azithromycin, a macrolide derivative structurally related to erythromycin, was developed at the end of the eighties $80^{6,7}$ and has been used in clinical practice for the treatment of various infections ${ }^{9}$. Its administration by the oral route, rapid passage into the intracellular compartments, slow release (a half-life of 2-6 days), and accumulation in various organs and tissues at high concentrations, especially in phagocytic cells, makes this drug an

1. Department of Infectious and Parasitic Diseases of Faculdade de Medicina do Triângulo Mineiro, Uberaba, MG. 2. Municipal Polyclinic of Araçuaí, MG. 3. Department of Pathology of Universidade Federal de Uberlândia, Uberlândia, MG. 4. Fundacion Huesped, Buenos Aires, Argentina. 5. Fundação Nacional de Saúde do Ministério da Saúde, Belo Horizonte, MG.

Adress to: Prof. Aluízio Prata. Medicina Tropical/ FMTM. Caixa Postal 118, 38001-970 Uberaba, MG.

Recebido para publicação em 20/9/2002. 
attractive option for the treatment of microorganisms that cause intracellular infections. In addition, therapeutic levels of this medication are maintained up to 5 days after the last dose administered ${ }^{14,15,19,22}$. Azithromycin shows good oral tolerance both in children and adults and has been successfully used in clinical practice administered as a single dose for the treatment of infections of the respiratory tract and skin and of sexually transmitted diseases, especially nongonococcal urethritis, as well as of ocular infections, especially trachoma ${ }^{20,21}$

In experimental and clinical assays, azithromycin has shown efficacy in combined therapy for the treatment and prophylaxis of infections caused by Mycobacterium avium intracellulare in AIDS patients ${ }^{9}$. The drug also proved to be effective in vitro against Toxoplasma gondii and in the prophylaxis of Plasmodium falciparum malaria, among other actions ${ }^{2}$.

The in vitro activity against Leishmania major was reported by Krolewiecki et $\mathrm{al}^{10}$. The good results obtained for four patients with cutaneous leishmaniasis, one of them with heart failure for whom treatment with an antimonial was contraindicated, stimulated us to assess the efficacy of treatment with azithromycin. Preliminary observations on hamsters chronically and massively infected with Leishmania Viannia brasiliensis (Lvb) and treated with this drug, after the cure of these patients, also revealed a favorable early response, although without complete resolution of the lesions (LE Ramirez: personal communication).

Preliminary results of this clinical assay, the first in the literature, have been presented previously ${ }^{16}$ and are now being completed with the present publication.

\section{POPULATION AND METHODS}

This pilot study was conducted from September 2000 to August 2002 in the municipalities of Araçuaí and Varzelândia (MG), where American tegumental leishmaniasis (ATL) is endemic and Lvb is the most common species.

The inclusion criteria were: patients older than two years with cutaneous lesions of less than six months duration compatible with a diagnosis of ATL, and absence of specific treatment for this disease in the last three months. Individuals with debilitating chronic diseases, pregnant women and patients with a history of intolerance of, or allergy to, macrolides were excluded.

The definition of an ALT case was based on the presence of cutaneous lesions with suggestive clinicalevolutive characteristics. The patients were submitted to clinical examination, to the Montenegro skin test and to a punch biopsy of the lesion. The material obtained by biopsy was divided into two fragments respectively destined to histopathological analysis and to inoculation into hamsters.
Azithromycin (Zitromax ${ }^{\circledR}$ ) was administered by the oral route according to schedules of $500 \mathrm{mg} /$ day for 3 days, $500 \mathrm{mg} /$ day/5 days, $500 \mathrm{mg} /$ day/10 days and $1000 \mathrm{mg} /$ day for 2 days. The same doses were repeated monthly until full lesion healing occurred. The posology and doses of azithromycin used in the present study were based on those recommended for the treatment of bacterial infections (3-5-10 days), although wide variability exists about time of treatment. The patients were evaluated monthly and the clinical response, scored from 1 to 10 , was determined on the basis of border induration, presence of erythema, secretion, infiltration, and lesion size. Full reepithelialization was defined as the criterion of clinical cure.

It was decided that patients showing no favorable response to treatment with azithromycin would receive Glucantime $^{\circledR}$ at doses of $20 \mathrm{mg} / \mathrm{kg} /$ day for 20 days.

All patients signed a term of informed consent to participate in the study, which was approved by the Ethics Committee of the Faculty of Medicine of Triângulo Mineiro, Uberaba/MG.

\section{RESULTS}

Twenty-four patients with a diagnosis of cutaneous leishmaniasis were treated. Of these, 4 were excluded because, although they presented an early clinical improvement, they abandoned treatment after the $2^{\text {nd }}$ azithromycin cycle, so that it was not possible to assess the final result of treatment.

Of the remaining 20 patients, $12(60 \%)$ were males. Sixteen patients (80\%) were from Araçuaí, MG, 3 (15\%) from Varzelândia, MG, and 1 had acquired the disease in the state of Mato Grosso. Age ranged from 5 to 79 years. The time of lesion evolution was 1-6 months (mean: 3.7 months). In 15 individuals (75.1\%), the lesion was single and mainly located on the limbs. The most common lesion was an ulcer with or without the formation of a scab. Most patients were positive to the Montenegro test, with a compatible or positive biopsy, and Lvb was isolated from hamsters inoculated with a lesion macerate from two patients. The main epidemiological, clinical and diagnostic features are listed in Table I.

Table II presents the number of days and cycles of treatment. The number of tablets ranged from 3 to 36 , the number of days of treatment ranged from 2 to 10 , and the number of cycles from 1 to 5 . Since the interval between cycles was one month, the maximum duration of treatment reached 4 months in 4 patients.

In the evaluation of the results for the 20 patients who terminated the study period, 17 (85\%) were considered to be cured. The time for cure was 60 days for $6(30 \%)$ cases, 90 days for $7(35 \%)$, and 120 days for $4(20 \%)$ (Table II). The patients reported improvement of the aspect of the lesion since the very first days of treatment, with a reduction of hyperemia and secretion. 
Table 1 - Clinical-epidemiological characteristics of 20 patients with cutaneous leishmaniasis treated with azithromycin.

\begin{tabular}{|c|c|c|c|c|c|c|c|c|}
\hline Patient & Age & Gender & Time of evolution (months) & No.of lesions & Location of the lesion* & Type of lesion & Montenegro Test & Histo-pathology \\
\hline 1 & 79 & $M$ & 2 & 1 & LL & Ulcer-crust & + & \\
\hline 2 & 16 & M & 6 & 1 & UL & Ulcer & + & Compatible \\
\hline 3 & 23 & M & 1 & 2 & LL & Ulcer & + & \\
\hline 4 & 18 & M & 1 & 1 & LL & Ulcer-crust & - & Compatible \\
\hline 5 & 18 & $\mathrm{~F}$ & 4 & 1 & LL & Ulcer & + & Compatible \\
\hline 6 & 47 & $\mathrm{~F}$ & 4 & 1 & UL & Nodular & + & Compatible \\
\hline 7 & 52 & M & 6 & 4 & UL/LL & Ulcer & + & Inconclusive \\
\hline 8 & 39 & M & 3 & 1 & LL & Ulcer & + & Compatible \\
\hline 9 & 5 & M & 3 & 4 & HT & Ulcer & + & Compatible \\
\hline 10 & 60 & M & 3 & 3 & H-UL & Ulcer-crust & - & Positive \\
\hline 11 & 21 & $\mathrm{~F}$ & 6 & 1 & LL & Ulcer-crust & + & Compatible \\
\hline 12 & 15 & $\mathrm{~F}$ & 6 & 1 & $\mathrm{H}$ & Ulcer-crust & - & \\
\hline 13 & 32 & M & 3 & 1 & $\mathrm{H}$ & Ulcer & + & Positive \\
\hline 14 & 11 & $\mathrm{~F}$ & 6 & 2 & UL/H & Ulcer-crust & + & \\
\hline 15 & 40 & M & 2 & 1 & LL & Ulcer-crust & + & Inconclusive \\
\hline 16 & 45 & $\mathrm{~F}$ & 6 & 1 & $\mathrm{H}$ & Nodular & + & \\
\hline 17 & 65 & $\mathrm{~F}$ & 4 & 1 & $\mathrm{H}$ & Nodular & + & \\
\hline 18 & 51 & $\mathrm{~F}$ & 6 & 1 & UL & Ulcer-crust & - & Positive \\
\hline 19 & 14 & M & 2 & 1 & $\mathrm{H}$ & Ulcer & + & \\
\hline 20 & 9 & $\mathrm{~F}$ & 1 & 1 & LL & Plaque & - & \\
\hline
\end{tabular}

$\mathrm{UL}=$ Upper limbs, $\mathrm{LL}=$ Lower limbs, $\mathrm{H}=$ Head, $\mathrm{T}=$ Trunk

Table 2 - Therapeutic and evolutive aspects of 20 patients with cutaneous leishmaniasis treated with azithromycin.

\begin{tabular}{|c|c|c|c|c|c|c|c|}
\hline \multirow[b]{2}{*}{ Patient } & \multicolumn{5}{|c|}{ Azithromycin } & \multirow[b]{2}{*}{ Final result } & \multirow[b]{2}{*}{$\begin{array}{l}\text { Follow-up withou } \\
\text { relapse (months }\end{array}$} \\
\hline & Daily dose (mg) & $\begin{array}{c}\text { Duration of } \\
\text { the cycle (days) }\end{array}$ & $\mathrm{N}^{0}$ of Cycles & $\begin{array}{c}\text { Total no. of } \\
\text { tablets }(500 \mathrm{mg})\end{array}$ & $\begin{array}{c}\text { Duration of } \\
\text { treatment (days) }\end{array}$ & & \\
\hline 1 & 500 & 3 & 3 & 9 & 90 & Cure & 20 \\
\hline 2 & 500 & 3 & 1 & 3 & 60 & Cure & 18 \\
\hline 3 & 500 & 3 & 1 & 3 & 60 & Cure & 18 \\
\hline 4 & 500 & 3 & 1 & 3 & 60 & Cure & 18 \\
\hline 5 & 500 & 3 & 2 & 6 & 60 & Cure & 14 \\
\hline 6 & 500 & 3 & 3 & 9 & 90 & Cure & 14 \\
\hline 7 & 500 & 3 & 4 & 12 & 120 & Cure & 13 \\
\hline 8 & 500 & 3 & 4 & 12 & 120 & Cure & 13 \\
\hline 9 & 250 & 3 & 3 & 4.5 & 90 & Cure & 14 \\
\hline 10 & 500 & 10 & 5 & 36 & 150 & Treatment failure & \\
\hline 11 & 1000 & 2 & 4 & 16 & 120 & Cure & 13 \\
\hline 12 & 1000 & 2 & 2 & 8 & 60 & Treatment failure & \\
\hline 13 & 500 & 5 & 3 & 15 & 90 & Cure & 12 \\
\hline 14 & 500 & 5 & 3 & 15 & 90 & Cure & 12 \\
\hline 15 & 500 & 5 & 3 & 15 & 120 & Treatment failure & \\
\hline 16 & 500 & 5 & 3 & 15 & 90 & Cure & 11 \\
\hline 17 & 500 & 5 & 3 & 15 & 90 & Cure & 11 \\
\hline 18 & 500 & 5 & 4 & 20 & 120 & Cure & 13 \\
\hline 19 & 500 & 10 & 2 & 20 & 60 & Cure & 12 \\
\hline 20 & 250 & 10 & 2 & 10 & 60 & Cure & 11 \\
\hline
\end{tabular}

Since the first clinical check-up one month after azithromycin administration, we observed a substantial modification of the characteristics of the lesions (20-40\%) in 17 patients, especially disappearance of erythema and of secretion when it was present, and reduction of border induration and of the diameter and depth of the ulcerations. Reduced height and induration were also observed in the nodular and plaque forms. In three patients we did not observe any improvement in the aspect of the lesion after 30 days, these being the patients who were not cured.

Of the 24 patients who started treatment, $7(29 \%)$ were not considered to be cured, 4 of them because they abandoned treatment and 3 because of treatment 
failure. Those who did not respond to azithromycin received Glucantime ${ }^{\circledR}$, with two of them showing full lesion healing after 60 days of use of the antimonial drug and one being lost to follow-up.
All patients tolerated the medication without reporting any complaints and no recurrence of the lesions was observed in any of them during 14 months of follow-up.

\section{COMMENTS}

Although no control group was used, the clear change in the characteristics of the lesion observed in most patients from the beginning of treatment to cure suggests an evident effect of azithromycin and not spontaneous resolution, as eventually observed in the cutaneous form of the disease ${ }^{13}$.

In 6 cured patients (cases 2, 3, 4, 5, 19 and 20) who were less than 24 years old, the favorable clinical response was observed after 60 days of treatment. This fact suggests a more rapid response in young individuals which may be related to better absorption of the medication. The 17 patients cured with azithromycin were followed up for a maximum of 14 months and no recurrence of the lesion was observed in any of them, confirming the efficacy of this medication. The three patients who were not cured showed no changes in the aspect of the lesions after the first cycle. Despite the small number of patients, this observation may perhaps predict from the beginning an unfavorable response to azithromycin. Since two of them had a negative Montenegro test, it would be important to determine in a larger number of patients whether this fact may be of importance in terms of therapeutic response.

The rapid initial effect on the lesions may be rather due to the action of associated bacterial infections. On the basis of lesion evolution and number of cycles used, it was possible to determine that the response to treatment with this medication occurs more slowly than that classically observed with antimonials, suggesting a leishmaniostatic effect. A recent study complemented the evaluation of azithromycin, showing a dosedependent activity in the models used ${ }^{11}$. In addition, other effects of this medication have been described, such as stimulation of phagocytosis, chemotaxis and cytotoxic activity in addition to its immunomodulating action $^{823}$.

The efficacy of azithromycin observed in this patient series suggests that this medication could be a good therapeutic option for the treatment of cutaneous leishmaniasis caused by Lvb, especially considering the cost-benefit ratio and the fact that the medication is easy to administer by the oral route as a single daily dose and is well tolerated by the patients.

However, a larger number of patients should be evaluated in more controlled and randomized clinical trials in order to validate these results and to determine whether they can be extended to the mucosal forms of leishmaniasis and to the lesions caused by other leishmania species. Furthermore, it is necessary to identify the scheme (doses and duration) that would be more effective and efficient as a therapeutic proposal for this parasitosis.

\section{REFERENCES}

1. Alrajhi AA, Ibraim EA, DeVol EB, Khairat M, Faris RM, Maguire $\mathrm{JH}$. Fluconazole for the treatment of cutaneous leishmaniasis caused by leishmania major.New England. Journal of Medicine; 41(3): 1795-1800, 2002

2. Anderson SL, Berman J, Kuschner R et al. Prophylaxis of Plasmodium falciparum malaria with azithromycin administered to volunteers. Annals of Internal Medicine; 123:771-773, 1995

3. Berman JD. Human Leishmaniasis: Clinical, diagnostic, and chemotherapeutic developments in the last 10 years. Clinical Infectious Diseases; 24:684-703, 1997

4. Chang HR, Pechere JCF. In vitro effects of four macrolides (Roxithromycin spiramicin, azithromycin [cp62693], and A 56268) on Toxoplasma gondii. Antimicrobial Agents and Chemotherapy; 32:524- 529, 1988.

5. Deps PD, Viana MC, Falqueto A, Dietze R. Avaliação comparativa da eficácia e toxicidade do antimoniato de $\mathrm{N}$-metil-glucamina e do Estibogluconato de Sódio BP88® no tratamento da leishmaniose cutânea localizada. Revista da Sociedade Brasileira de Medicina Tropical; 33(6):535-543, 2000.

6. Foulds G, Shepard RM, Johnson RB. The pharmacokinetics of azithromycin in human serum and tissues. Journal of Antimicrobial Chemotherapy; 25(suppl A): 73-82, 1990.
7. Girard AE, Girard D, English AR, Gootz TD, Cimochowski CR, Faiella JA, Haskell S, Retsema JA. Pharmacokinetic and in vivo studies with Azithromycin (CP-62,993), a new macrolide with an extended half-life and excellent tissue distribution. Antimicrobial Agents and Chemotherapy; 31(12)1948-1954, 1987.

8. lanaro A, lalenti A, Maffia P, Sautebin L, Rombola L, Carnuccio R, luvone T, D'Acquisto F, Di Rosa M. Antiinflammatory activity of macrolide antibiotics. Journal of Pharmacology and Experimental Therapeutic; 292: 156-163, 2000.

9. Koletar SL, Berry AJ, Cynamon MH, Jacobson J, Currier JS, MacGregor RR, Dunne MW, Williams DJ. Azithromycin as treatment for disseminated Mycobacterium avium complex in AIDS patients. Antimicrobial Agents and Chemotherapy: 43(12):2869-2872, 1999.

10. Krolewiecki AJ, Scott P, Abraham D. The anti-Leishmania activity of azithromycin in an in-vitro model. Revista da Sociedade Brasileira de Medicina Tropical; 32(supl II):137, 1999.

11. Krolewiecki A, Leon S, Scott P, Abraham D. Activity of Azithromycin against leishmania major in vitro and in vivo. American Journal of Tropical Medicine and Hygiene; 67(3): 273-277, 2002.

12. Marsden PD. Pentavalent Antimonials: Old Drugs for New Diseases. Revista da Sociedade Brasileira de Medicina Tropical; 18(3):187-198, 1985. 
13. Navin TR, Arana BA, Arana FE, Berman JD, Chajon JF. Placebo controlled clinical trial of sodium stibogluconate (Pentostam $)^{R}$ versus ketoconazole for treating cutaneus leishmaniasis in Guatemala. Journal of Infectious Diseases; 165:528-534, 1992.

14. Neu HC. Clinical Microbiology of Azithromycin. The American Journal of Medicine; 91(suppl 3A):12S-18S, 1991.

15. Peters DH, Friedel HA, McTavish D. Azithromycin. Drugs; 44(5): 750-799 1992.

16. Prata A, Silva-Vergara ML, Costa L, Rocha A, Krolewiecki A, Silva JC., Paula EV, Pimenta JR FG, Ramirez LE. Eficácia da azitromicina no tratamento da leishmaniose cutânea. Revista da Sociedade Brasileira de Medicina Tropical; 34 (Suppl. III): 133, 2001.

17. Romero GAS, Guerra MVF, Paes MG, Macedo VO. Comparision of cutaneus leishmaniasis due to Leishmania (Viannia) brasiliensis and $L$. $(v$.) guayanensis in Brazil. Therapeutic response to meglumine antimoniate. American Journal of Tropical Medicine and Hygiene; 65(5): 456-465, 2001.

18. Saldanha ACR, Romero GAS, Guerra C, Merchan-Hamann E, Macedo VO. Estudo comparativo entre estibogluconato de sódio BP $88 \AA$ e antimoniato de meglumina no tratamento da leishmaniose cutânea II. Toxicidade bioquímica e cardíaca. Revista da Sociedade Brasileira de Medicina Tropical; 33(4):383-388, 2000.

19. Schentag JJ, Ballon $\mathrm{CH}$. Tissue directed pharmacokinetics. American Journal of Medicine; 19(Suppl 3A):55-115, 1991.

20. Stamm WE, Hicks CB, Martin DH, Leone P, Hook EW 3rd, Cooper $\mathrm{RH}$, Cohen MS, Batteiger BE, Workowski K, McCormack WM. Azithromycin for empirical treatment of the nongonococcal urethritis syndrome in men: a randomized double-blind study. Journal of American Medical Association; 274: 545-549, 1995.

21. Tabbara KF, Abu el Asrar, Al-Omaro et al. Single dose azithromycin in the treatment of trachoma, a randomizad controlled study. Ophtalmology; 103:852-856, 1996.

22. Wildfeuer A, Laufen $\mathrm{H}$, Zimmermann T. Uptake of azithromycin by various cells and its intracellular activity under in vivo conditions. Antimicrobial Agents and Chemotherapy; 40(1):75-79, 1996.

23. Xu G, Fujita J, Negayama K, Yuube K, Hojo S, Yamaji Y, Kawanishi $\mathrm{K}$, Takahara J. Effect of macrolide antibiotics on macrophage functions. Microbial Immunology; 40: 473-479, 1996. 